\title{
乳牛のケトーシスについて
}

中 村 良一*

緒言

乳牛のケトーシスに関しては, 外国では1928年頃に注 目されて以来, 今日相当なところまで研究が進められて きたが，わが国で本格的に研究の対称となったのは極く 最近のことである.すなわち梅津ら (1951) による, 反 忽獣の胃の消化機構江関する基礎的研究の着手を契機と して, 従来わが国で関心をもたれなかったケトーシスが 一躍学会に登場した。爾来一時末端の臨床家はケトーシ 熱にうなされた感さえあり，ひいては乳牛の万病がこ れケトーシスなるかの誤謬さえ生じたナンセンスもあ る.

そもそもケトーシスなる学間的意義は, 極めて深遠な るものの如く, その原因学的解明は, 未だ先進諸外国に 技いても十分なる結論が得られていないと見て差支えな からう. 本症は従来炭水化物の不足ないし欠乏飞起因 し, 脂肪代謝障害による体内のケトン体の異常蓄積を 見, 同時泜低血糖症を惹起して, 牛体海床的有害反応 が現われるもので，これには第 1 胃の消化 $\rightarrow$ 肝臓の働き があずかって大いなる役割を果するのとされていたよう である、しかしながら，ケトーシスが単なる炭水化物の 欠乏なりとの見解を支持する科学的根拋はなく，炭水化 物の欠乏のみをケトーシスの原因とすることは誤りなり とする者もいる(Daugherty, Duncanら, Henderson, VIGUE). すなわち VIGUE (1952) 飞よると, 脂肪や炭 水化物はェネルギーの要求の目的で使用され, これには 肝藏が大いに役割を思するのであるが，肝臓はこれらの もの拉よび蛋白代謝極めて重要であり, 肝臓ではアミ ノ酸がブドウ糖に变えられる.脂肪や炭水化物が使用さ れると, カロリーは肝臓や他の器官拉よび組織の蛋白が 利用されるが, これらの蛋白は炭水化物变化し, ある ものはカロリーの要求を満すため脂肪に变化すると述べ ている、また ToLLY は, 牛乳中の蛋白は血液蛋白から 誘導されるから, 高能率4:の肝蔵は常にストレスの下に 置かれるという，そして蛋白の合成にはすべてのアミ， 酸が必要とされ, 胎仔は最後の 3 月にその $2 / 3$ の大きさ が発達するので, 乾乳期淤ける低蛋白招よび高炭水化 物による飼養は，ケトーシスを起させる素地を作るとい 5.よって朋の蛋白は妊娠末期, 搾乳初期和よび疾病時 そは, 他の器官に叔けるより多量の消失をきたし, 飢餓 時にはとくにその消失が速かである。すなわち, これが 原因は不適当な飼養が重点とされ, 飼料の量拉よび質が

* 北海道大学獣医学部
問題視されるが，しからば如何なる比例で蛋白を摂取し たら糖化能力を維持し得るかは，未だ明らかにされてい ない.すなわらケトーシスの原因は, 第 1 胃の消化機構 を中心とし，上述の如き栄養学的基礎に立脚した観点か ら追究されつつある.

また一面，ケトーシスをS SELYE のストレス説から見 るとき，しばしば一時的のアドレナリンの久竞を伴い, これは脳下垂体一副腎皮質系ホルモンを包含する，いわ ゆる沉適応症候群の一時期を現わしているものであり, 妊娠末期, 分婏, 分婏後の㩁乳などは, 正常斗汸和いて る比較的ストレスとなるものである。このストレスは脳 下垂体を刺激して ACTH を放出し, ACTH は副腎を 刺激して抗炎性の glucocorticoids を分泌させるが，こ れによって特はストレスに打勝つことができる.すなお ちこれがため一部ではブドウ糖の增量により, また一面 蛋白から新しいブドウ楉を形成することによって, 栄举 の均衡を保っている. しかるにケトーシスの場合は, ス トレスが過度となり, 従って脳下垂体は異常に刺激され るため, これが一時的の疲労をきたするのと仮定されて いる.このことは正常な代謝がもはや維持し得ざる結 果, 副腎では十分な glucocorticoids を作り得ざる状態 となり，血糖の低下执よびケトン体の增量をきたし，よ ってケトーシスの症状が現われるとされている.すなわ ちケトーシスが，脳下垂体一副腎皮質系ホルモンを包含 する，いわゆる内分泌機構の不調によるとされる所以の もので, 基礎的にもまた臨床的にも大いに検討されつう ある.

上述の如く, 本症は一面栄養学的汇また一面内分泌学 的に, 両面からそれ年れ別個に研究されているかの如く 考兄られるが，この両者はまた相互に密接な関連を有す るものである.とくに本症をストレスの上から見ると き, 矢の病要因は極めて複雑多岐にわたり, 妊娠, 分 婏および泌乳を中心とする，いわゆる飼荃管理の失宜な るものが包含されると思われる.

著者は 4 月17日札㒻において，はるばるカナダよりこ られた S SELYE 博士のストレスに関する講演を扯聴し， このストレスについてはさらに感を新にすることができ た。

ひるがえって, 最近汸けるわが国の乳牛を疾病学的 飞見るとき，先の原因は飼養管理の失宜に帰されるもの

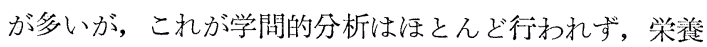
障害の重大さが痛感され, ようやくこの面の本格的研究。 の兆が現われた. われわれはここ数年来, 内科学とい5 
立場から，まずケトーシスなるものの臨床的意義を解明 する目的で, 多くの乳牛についてケトン体を中心に臨床 および血液学的の観察を進めてきた。これを栄養障害な る観点から検討するとき，未だ業績は極めて拙劣ではあ るが，今までに収めた諸結果とその他研究者の成績を取 りまと斗, 専ら臨床的分野から本症の概要を述べて今後 の参考供したい。

病

名

多くの交献を見ると，Ketosis と書かれ，あるいは Ketonemia, Ketonuria, Acetonemia 拈よび Acetonuria そいう記載がある.もちろん多くの研究者は, こ れらの意義执よび用法については知り尽されていられる ことで, 今さらながら改めて注釈の要はないが，一般臨 床家のうちでは，これを疑間視される方があるので，著 者の見解を簡単飞述べて見たいと思う。

1. ケトン体 (Ketone body)：普通ケトン体という が,これはアセトン(Acetone),アセ卜醋酸 (Acetoacetic acid）扔よびべタヒドロキシ酪酸（ $\beta$-hydroxybutyric acid）の総称で, 総ケトン体と称する者もいる.それで 本症の診断に，古くはいわゆる総六ン体を測定したの で,この場合とくに総ケトン量またケトン量といい, ア セトンのみを遊離させた場合アセトン量と，それぞれ区 别している.

2. アセトン血症 (Acetonemia) 抢よ゙びアセトン尿 症(acetonuria)：血中招よび尿中の遊離アセトンを測定 て，これが異常に增量せる場合をいう。

3. ケトン血症 (Ketonemia) 扣よびケトン尿症 (Ketonuria)：血中また尿中の総ケトン体の増量せる場 合であると解する.

4. ケトーシス(Ketosis) : Ketosis といらからには, 一つの疾病である.よって明かになんらかの臨床症状を 認めると同時に, ケトン体またアセトンの異常增量, す なわち Ketonemia, Ketonuria, Acetonemia あるい は Acetonuria の状態ひあるものを Ketosis と称すべ きものと解釈する. 従って臨床上はなんらの变化なく, 単炕ケトン体またアセトンの夕の增量は, ケトン血(尿) 症またアセトン血(尿)症と称すべきもと思う。

しかしながら，通常われわれが耳にするのは，いずれ の場合をる Ketosis と呼称されているので, 今後はこ れらの用語を明確に区别して报らならば，它の病性を知 る上飞極めて便利なことと考える.

$$
\text { 病性 }
$$

\section{1. 発病要因}

本症の発病動機となる主なる因子をあげると次の如く である (Christian ら, Hayes, Henderson, Jordan, Milis, Sampson, Shaw b, Udali).
（1） 発生の時期：本症は妊娠末期, 泌乳の初期, 分婏 後10日〜2 月あるいは高度の搾乳期に，また季節的には 晚秋から晚春にかけて発生しやすい。

(2) 年令: 年令的注壮令のもので, $3 \sim 4$ 回の経産 牛, また初産牛に多く, 乙か子泌乳能力の旺盛なものに 発生しやすい。

（3）飼養管理：舎飼牛で, 臨床的には栄養の良好と思 われるものに多いが, 栄養学的には飼料配合の不適に大 い関係するようであり，また慨餓の状態でも発病す る.

（4）怹の疾病の随伴：消化不良，創傷性胃炎特よび心 膜炎, 乳熱, 後産停滞, 子宮内膜炎, 乳房炎招よび白血 病, 並びにその他感染病にも随伴することがある.

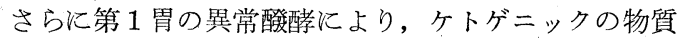
が作られる，いわゆる異常消化の状態に扔いても本症を 発生する(C.AlGت).

(5) ストレスの考党：分怨汇続いて起る泌乳は，今ま での無乳状態から, 短時日に急激な乳の大量生産に移行 するため，牛体に肉体的のストレスとなり，李た過学， 寒冷招よび酷暑もストレスとして作用し，ここにケトー シスの発生を見る (CйRIstian, Shawら).

(6) 余らの調查: 余らは多くの䠦床的健康牛の血液拉 よび尿につき，ケトン体；血桾扤よび好酸球の動向を調 べ，これらの堌隇を左有する内外諸因子を指摘し（日本 獣医師会誌, 10巻, 1 号, 1957), 次の如き見解を持っ た.すなわちケトン体は 3 才以上では年令の增加ととも 飞增量する傾向があり,また妊娠初期拉よび末期並びに 妊牛は非妊牛上り，それぞれケトン体が增量している。

また $2 〜 5$ 経産牛掞よび分婏回数の多いものほど,さら 飞泌乳量の高度なもの活どケトン量の增加が認められ た。季節的には晚秋から晚春にわたり，しか子飼養管理 の良好なもの添どケトン量が多い。しかしてこれら臨床 的健康牛性, 推計学的処理の結果, 第 1 表江示す如 $<$, いわゆる normal と subclinical の 2 群と分けられ， 後者は沉適応症候群の抵抗期俍該当するものと考察し た。

第 1 表 臨床的健康牛

\begin{tabular}{|c|c|c|c|c|c|c|}
\hline \multirow{2}{*}{ 区 } & \multirow{2}{*}{ 臨床症状 } & \multicolumn{3}{|c|}{ ケトン皆 } & \multirow{2}{*}{ 血糖量 } & \multirow{2}{*}{ 好酸球数 } \\
\hline & & 総r & トン & アセトン & & \\
\hline 正 常 群 & - & 正 & 常 & 正 常 & 正 常 & 正 常 \\
\hline 亜正常群* & - & 增 & 加 & 堌 加 & 增 加 & 減 少 \\
\hline
\end{tabular}

第 2 表 諸種疾病牛

\begin{tabular}{|c|c|c|c|c|c|c|c|}
\hline \multirow{2}{*}{ 区 } & \multirow{2}{*}{ 臨床症状 } & \multicolumn{4}{|c|}{ ケトン量 } & \multirow{2}{*}{ 血糖䁷 } & \multirow{2}{*}{ 好酸球数 } \\
\hline & & 総ケ & トン & 阝t & トン & & \\
\hline ケトーシス群 & + & 增 & 加 & 増 & 加 & \multirow{2}{*}{$\begin{array}{l}\text { 減 少 } \\
\text { 減少 } \\
\text { ～増加 }\end{array}$} & \multirow{2}{*}{$\begin{array}{c}\text { 増 加 } \\
\text { 減少 } \\
\sim \text { 増加 }\end{array}$} \\
\hline 諸種疾病群 & + & 正 & 常 & ～増 & 加 & & \\
\hline
\end{tabular}

日獣会䄊 10 (1957) 
次に多くの諸種疾病牛につき, 健康牛に和けると同様 な検查を行ったところ, 第 2 表淿示す如く, ケトーシス ではケトン量の增加, 血糖量の減少和上び好酸球数の堌 加が顕著であるが，その他の疾病群ではケトン量は正常 〜増加, 血糖量抢よび好酸球数はともに減少〜増加の現 象が見られた。すなわちこれらを沉適応症候群の上から 見ると，ケトーシスは疲学期汇該当し，また諸種疾病群 は抵抗型と疲労型の 2 つ分けられる. よってこの事実 から, 本来のケトーシス以外の諸疾患飞执いても, 結果 的にはケトーシスの状態を随伴するものの多いことがわ かり，これはいわゆるストレスによるものと考觉て差支

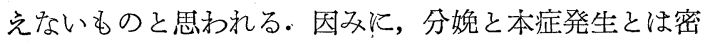
接な関連を有するところから，若干例につき分婏後の血 液性状を見たので，ここにはその 2 例を紹介して見た い.すなわち第 3 抢よび第 4 表に示した如く, 泌乳量, ケトン量敌よびブドウ糖量の 3 者の関係を見ると, 極め て興味あることと思う。

第 3 表 分娩前後の血液成分の消長 (ホル種, , 3 才)

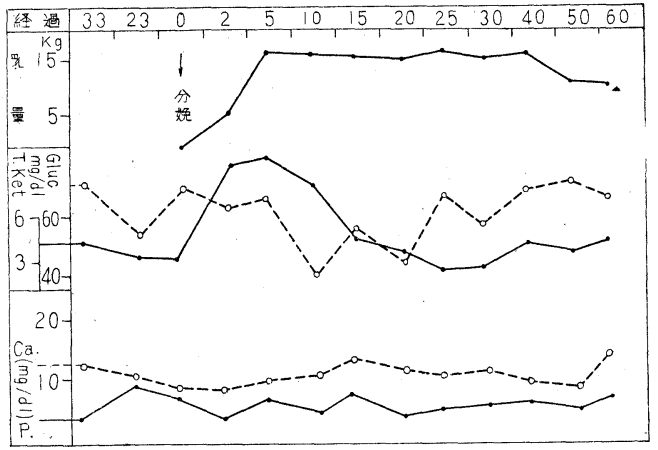

第 4 表 分婏前後の血液成分の消長 (ホル種, 우, 7 才)

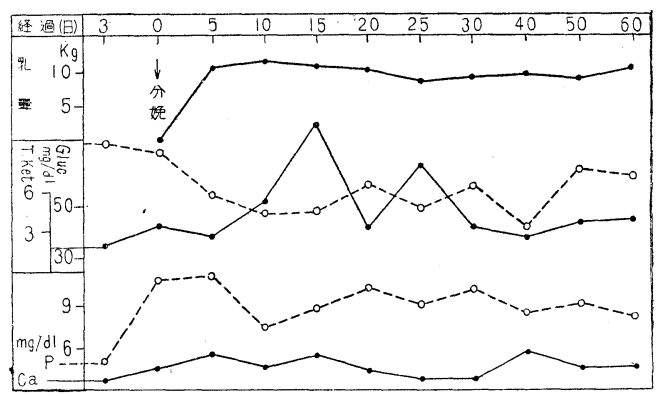

\section{2. 臨床的観察}

本症の病型については一定の見解がない。著者の観察 からすれば, 単独症と随伴ないし合㐿症の 2 つに大别し て考光るのが妥当のように思われる．従来の諸外国に拉 ける取披い方を紹介すると次の如くである.

\section{A. UDALL の分類}

発病要因を基礎に次の如く分けている.

（1）Parturient (分婏性) ketosis：これは分婏後 2〜
3 日で発病し, 多く乳熱様の症状を伴う。

（2）Non-parturient (非分婏性) ketosis：分婏後30 日以内に発病し, 多く消化不良の症状を伴 5 . 乳熱様の 症状を伴了ものは少なく, また他の疾患の随伴症状とし て，尿中のアセトンが增量する.

病型は次の 3 つ分けられている.

（1）Digestive type (消化型)：分婏後 10 日～6 週あ るいはそれ以上で発病し, 食欲欠損, 泌乳減退, 歩様跲 跟括よび削瘦を見，体温は正常である。

(2) Nervous type (神経型)：前者より病勢が重く, 痓戀その他運動障害㧍よび不全麻痺を現わす。

- (3) Milke fever type (乳熱型): 乳熱に類似した症 状を現わす. 乳熱の治療を行らも,な和麻瘦が消退せ ず，症状の再現する場合はケトーシスを疑ってよい。

CRAIGE (1953) は, この乳熱型に相当するものを, Chronic milk fever (慢性乳熱) と称している.

その他肺炎, 創傷性胃炎怙よび子宮内膜炎などが共存 すると，尿中のアセトンは陽性であるが，ケトーシスと しての症状は明らかでないという。

\section{B. SAMPSON の分類}

1. Physiological (生理的) 拈よび Pathological ketosis (病理的)

(1) 生理的ケトーシス：なんら症状は認められない が, 血液拉よび尿のケトン体が陽性の場合で, これは臨 床家の大いに注意せねね゙ならねところであると警告を発 している.

(2) 病理的（臨床的）ケトーシス：ケトーシスの症状 が著明で，しかも血液祆よび尿のケトン体が陽性の状態 を称し, 臨床上明らか汸トーシスと診断し得るもので 妊娠拉よび搾乳中に限られるという。しかして食欲捄よ び泌乳の減退, 体重の急減, 粘液附着の排瓷䇽よび起立 不確実などの症状が認められる.

2. Uncomplicated (単独) および Complicated(合 併) ketosis

（1）単独症: ブドウ糖の注射むるいは他の炭水化物に よる治療で回復するか，または自然に治癒する。

（2）合併症: 炭水化物療法で, 低血桾症怙よびケトン 血症 (また疗症) が回復せぬ時は, 本症の增進期か, あ るいは他の哭患との合併したものと見てょい。すなわち， 消化器の障害, 子宮内膜炎, 創傷性胃炎〜心膜炎などに。 多く見られ, さらに腎その他の器官の障害に併発するこ とがある。

C. SiHAW らの分類

（1）䬣餓性ケトーシス：低血糖症拈よびケトン血症を 起し，肝グリコーゲンの隇少が著明であるが，典型的な 症状起欠

（2）自発性ケトーシス：低血糖症执よびケトン血症を 起し, 食欲拉よび泌乳の減退, 体重の急減, 歩様不確 
実，昏睡なた興奮を見る・

D. MCAuLiFF の分類

(1) 原発性ケトーシス (単純ケトーシス)：血糖量 40 $\mathrm{mg} / \mathrm{d} 1$ 以下和よびケトン量 $10 \mathrm{mg} / \mathrm{dl}$ 以上で, 食欲括よ び泌乳の減退を見，便秘勝ちである．しかして乳熱様症 状が現われた場合，真の乳熱では瞳孔反射を欠くがケト ーシスに由来するものは該反射の存する点で区別すると いう.

（2）継発性ケトーシス：これは他の多くの疾患に随伴 するものである・

以上の如く，ケトーシスを报 5場合，発病要因和よび 病勢の上から，人によりそれぞれ表現法は異るが，着眼 するところは滦とんで変りないと思われる・ただわれわ れの注意すべき点は，SAMPSON のいう如く，いわゆる 生理的ケトーシスで，単にケトン量のみによる本症の判 定には警告を発したい。乙かして余らが日常遭遇する病 型のものは，UDALL の消化型のものが多いが，著者は

第 5 表 慢性鼓脹症のPionate による治療試験

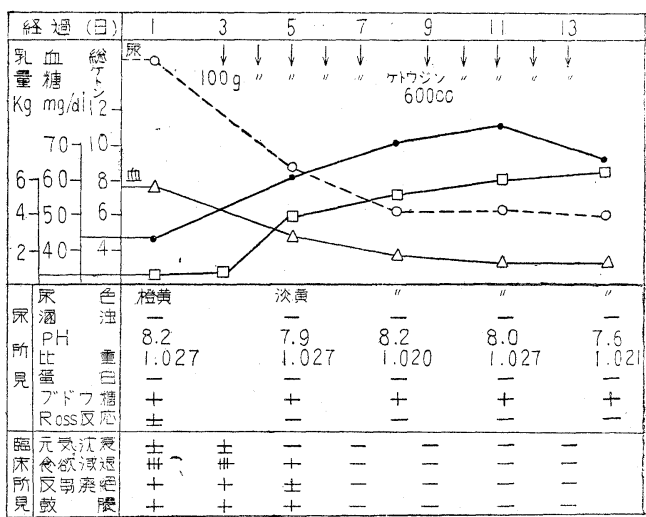

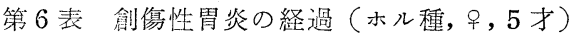

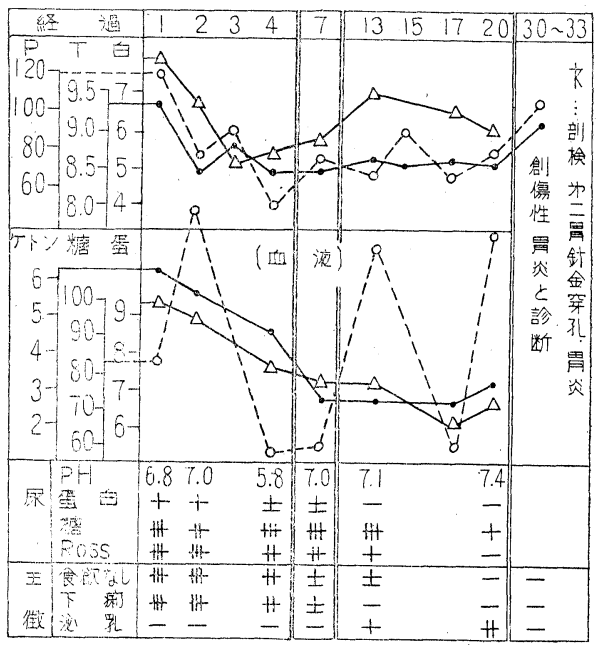

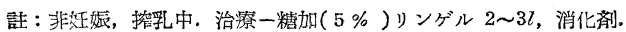

第 7 表 乳熱 (우，7才，分婏後 3 日)

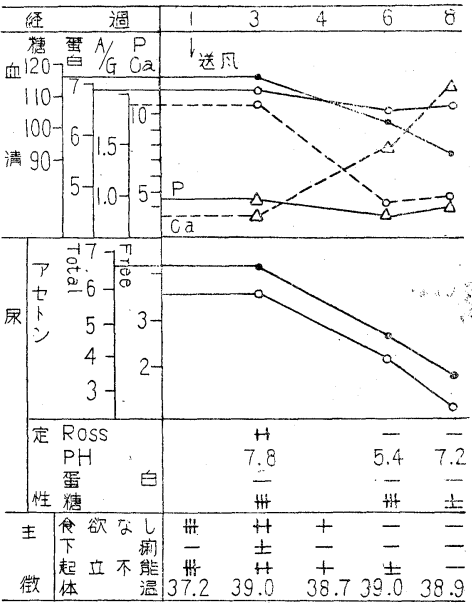

治蟟 : 送風, ブドウ糖カルシウム剂, 強心剂

第 8 表 産裖性血色素尿症(ㅇ, 9 才, 分婏後 2 週)

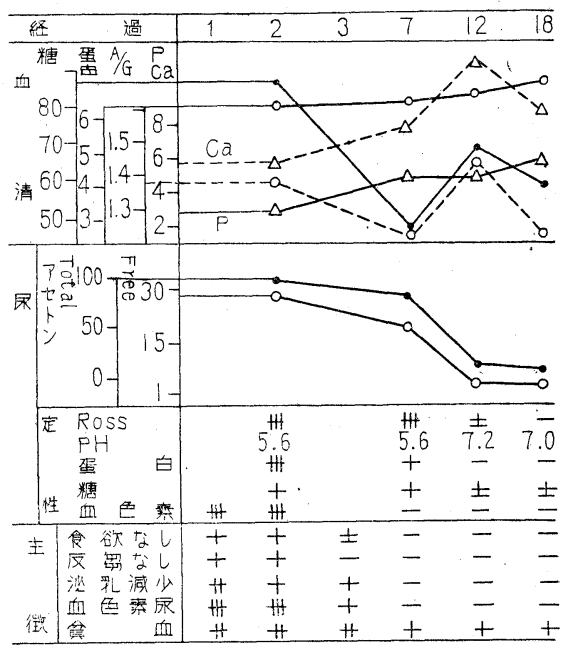

治療：リソゲル, Ca 竗, 橉酸ソーダ

UDALL の分類にさらに随伴型（ないし合併型）を追加 したい、因みに，著者が取报った随伴型と思われる臨床 例を第 $5 \sim 8$ 表に紹介して見よう.すなわち鼓脹症, 創 䇚性胃炎, 乳熱括よび産裖性血色素尿症を見るた, ケト ン血（尿）症またアセトン血（尿）症は，いずれも治療 経過につれて消退したことから，これをもって直らにケ トーシスの治瘉と見做すことは当を得ない。

\section{3. 病理学的所見}

ケトーシスの患牛はその多くが飼養管理の失宜による ものであり，これが改善ないし治療によって治疹するた め, 死亡率は極めて少ないように思われる. 従って死後 の病理学的記載は少ない. 余らの报った臨床例に和いて も, 未だケトーシス牛の病理学的検討を行っていない が，研究のあり方としてははなはだ片手落ちなことで遺

日獣会誌 10 (1957) 
憾としている.よってここには, UDALL, ShaW らおよ び HeNDERSCHOTT らの記載の概要を紹介することとす る.

（1）肝臓：肝臓は代謝を司る最も重要な器官で, 本症 では脂肪浸潤ないし変性を起し, また肝硬変も認められ る.

（2）副䁂皮質：副腎皮質は著明に肥大し，また変性， 線維化，皮質に和ける多型核游走細胞和よび巨大細胞の 浸潤が見られる。

（3）脳下垂体前葉：脳下垂体前葉は重度の退行変性を 見,リンパ細胞の浸潤および萎縮をきたす。

（4）組織：内分泌腺执よび上皮細胞はともに变性が著 明である.また膵蔵は萎縮する。

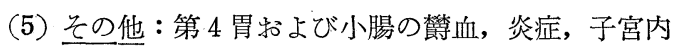
膜炎扣よび腎炎などが認められる。

以上が主なる報告の要録であるが，就中肝蔵，副腎皮 質および脳下垂体の変化は, 本症の重要な所見の如くで ある.な抗これが病理学的検討は, 栄養障害の一環とし て, 詳細なる研究を必要とする。

$$
\text { 診断 }
$$

本症の診断には, 臨床抢よび生化学的の検查を必要と する.

\section{1. 臨床診断}

臨床的には, 元気食欲の減退ないし廃絶, 瘦削和よび 泌乳量の激減を特徵とし, 多く発熱を伴わない.すなお ち大部分は消化型のもので, 神経型および乳熱型と称す るものは極めて少ない。㐬た消化障害を起す如き諸疾患 《随伴する, いわゆる随伴型のものも多いが, これらは 合併症とも称すべきもので, 必らず原病固有の症状を有 乙病勢により発熱を伴う. 従って類症鑑別に当り, 原発 的ケトーシスと上述の如き単なる消化障害との区別はは なはだ困難である.よって必らず生化学的診断法を併用 すべきである。

また余らの血液所見で, 軤床上健康と思われる乳特あ るいはケトーシス患牛に括いて, 赤血球数抽よび血色素 量の減少をきたすもの, 寸なわち貧血を呈するものがあ る.さらにこれらは, 低蛋白血症を惹起し, かつ血中の $\mathbf{P}$ 抢よび Caなどの関連性をも検討中であるが，これが ケトーシス解明に如何なる意義があるか, 今後の検討に ゆずりたい.

\section{2. 生化学的診断}

ケトーシスの診断に最も有力な指標となるのは, 血液 および尿中のケトン量と血糖量の增減であるが, 著者は さらに好酸球の動態をむ重視している.

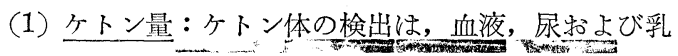
汁が対称とされるが, 通常は前 2 者が用いられる.しか も従来の検出は総ケトンまたはアセトンなどで一定の規
準が定められていない.わが国では栄養障害研究委員会 の提案に基き, 一応血液のアセトン体を取り上げてい る. もらろん実際的には尿が最も簡便であるが，高低の 差異がはなはだしいため,さらに検討の余地が残されて いる.

ケトン量の生理的および病的の限界は, 健康時におい ても飼養管理の状態によって相当の開きがある. 著者が 臨床的健康牛执よびケトーシス患牛について調查した結 果は，第 9 および第10表に示した如くである.すなわち 臨床的健康牛を, 統計的飞処理すると正常群之覀正常群 に分けられ，このうち亜正常群のケトン量は正常群のそ れに比べ，はるかに多い。しか子後者は臨床的には著变 なき点から，いわゆる subclinical のもので，ケトーシ スの一歩前のものと考光てよい. しかしてケトーシス群 ではさらにケトン量の增加が目立っている.よってこの 場合，血液アセトン量を指標とするならば，10mg/d1 以 上をケトーシスと見なしてよいと考觉る.

第 9 表 血液ケトン体検出成績

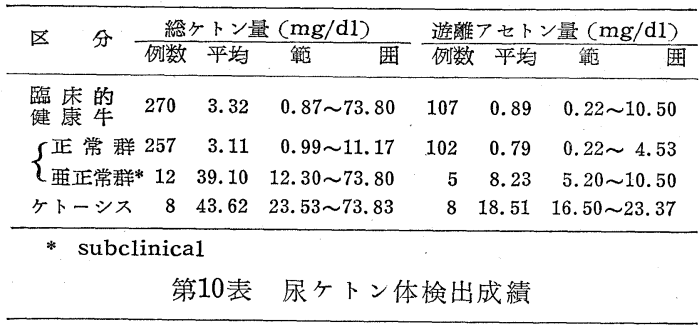

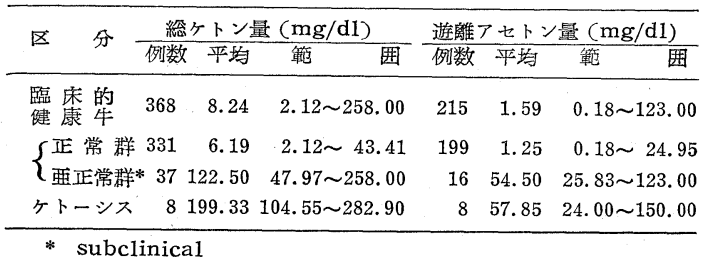

しかしてケトン体の検出には，拡散法によることが最 もよいが, 野外の臨床的には, 余らが各種簡易テストの 比較検討を行った結果から見ると,シノテスト 3 号法が 適当のように思われる。

（2）血糖量：ケトーシスでは低血桾をさたすことか ら, 血糖の定量も重要である. 著者らの多くの健康牛に ついての測定值は平均 $62.1 \mathrm{mg} / \mathrm{dl}$ で, 標準偏差は 20.2 である.しかも正常群执よび亜正常群とも, ケトン量の 多くなるにつれ血糖量は増加する傾向があるが，ケト一 シス群では平均 $44(20 \sim 57) \mathrm{mg} / \mathrm{dl}$ で, 健康牛に比べ 低血糖の状態にある.もちろ几健康牛活いても, 飼料 のいかんに左右され，相当の開きはあるが，余らの調查 結果から見ると, 招和む水 $60 \mathrm{mg} / \mathrm{dl}$ を健否の限界とし て差支充なから。

(3) 好酸球：ケトーシスを汎適応候群の上から見る と, 好酸球の動向が注目されてよい. 余らの調査した健 


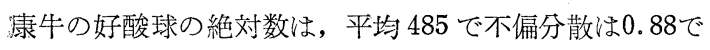
西る。そしてケトン量の增加するもの泀ど好酸球数は減 少しているが, ケトーシス群では逆汇增数し, 平均 1,270 (800〜1,800)である.

\section{3. 類症鑑別}

（1）単なる消化不良特よび乳量の減少をむって值ちに ケトーシスとするは早計である. 両者は互に因果関係を 有するので, 禀告扣よび現症を詳細に検討するととも 飞，必らず生化学的診断を併用すべきである。

（2）合併症との鑑別：炭水化物の治療で症状の消退せ 邓時は, 本症の増進期かまたは他の疾患々の合併症であ る(SAMPSON).さらに $50 \%$ dextrose を静注し,24時間 以内で元気食欲の回復を見る時はケトーシスと察して, さらにこれが治療を継続する.症状の好転せ婸合は, 他の疾患との合併症を考学るべきである(CRAIGE).

（3）乳熱特よび乳熱様疾患との鑑別：乳熱の諸治療を 行うも,な和麻痺の消退も見ず,かつ乳熱の症状が再現す る時はケトーシスに由来するものと見てよい(UDALL). また乳熱では瞳孔の反射がないが，ケトーシスではこの 反射が存するという (MCAULIFF).すなおち乳熱とケト ーシスでは, 臨床および血液化学面から, Ca, P, 血糖 およびケトン体などの動態が論ぜられるところであり， いうゆ true acetonemia (真性アセトン血症) 特よび chronic milk fever (慢性乳熱) 々称される (C RATGE) 所以のもとであろう.

以上述べた如く, 余らの検查した結果では, ケトーシ スの診断には今のところ, 少くも臨床所見以外の 3 つ 因子が検討さるべきもので, ケトン量のみによっての判 定は, 本症発生の経緯からしても当を得好のと考光る. 乙かも上述の計数的問題は, すべて比較的のものであ り, あくまでも第 1 㐨よび第 2 表に示す如き事実から, Physiological, Sub-clinical および Pathological の 区別を明確にし，さらに類症鑑別を行うことが必要であ る. 李た将来は, 蛋白, 肝㵴の biopsy までに発展する やる知れないが，これは栄養障害研究の一環として，今 後に残された重要な課題である.

\section{治療}

本症の治療には, 現在広く応用されているもの, ある いは試験的の域を脱せ邓ものなど多数あるが，一応ここ には，文献に現われたものを紹介することとするまず 有機物から述べると次の如くである。

\section{1. ブドウ糖}

ブドウ糖は本症の治療に古くから用いられ，乙かも最 も使用し易い一般的のものとして推賞されてきたが，そ

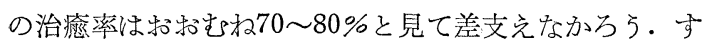
なわちここに病性との関連性があり, 治潦上大いに考慮 すべき点が伺われる，従来の諸成績を総合すると次の如
くである.

まず投与法は経口と注射の 2 つがあるが，大多数は静 脈内注射 (以下静注) が試みられている。すなわちブド ウ糖溶液, その他の炭水化物をそれぞれ 1 日数 $1 \mathrm{~b}$ 投与に よって, 重症例は 1 週で治瘾し (SAMPSON \& BOLEY), また静注は一時的で, 上界した血糖值は 90 分以内に注射 前の值に復すため, 経口投与を推賞するとともに, 血桾 の上昇値を維持するには皮下注射(以下皮注)がよいとい う者もいる(HoLMES). また糖密を1日 2 回 1 1.5pint (1pint $=0.47 \mathrm{~L}=$ 約 2 合 6 勺余)与之(ROBERTS \& Dye) さらに静注では $40 \sim 50 \%$ 液を 1 日 1 回 $500 \sim 1,000 \mathrm{cc}$ 宛 数日用いているが (Batley, Diernhoper, Givgras, Johnson, Kingma, Roberts, Roberts \& Dye, SampsoN), 多くは $1 \sim 2$ 回では所期の目的が得られず, 数時 間毎の反復注射がよいとする報告もある (Johnson, KINGMA). とくに RoBerTs \& Dye (1951) によると,ブ ドウ糖 $40 \%$ 液500〜 1, 000ccを静注するときは, 通常 2 4 時間で血糖量は増加するとともにケトン量の減少を見 るが， 1 ～時間後には再び血糖量の滅少揖よびケトン 量の增加をきたす。すなおち注射されたブドウ糖の多く は, 注射後短時間で尿中渄泄される故連続注射する必 要ありと述べ，彼独特の連続注射法を案出した。すなお ち溶液の注入割合は 1 時間 $150 〜 200 \mathrm{cc}$ 最適なりとし， 90時間を要した例がある.な新彼らは連続注射に先立っ て,ブドウ糖 $40 \%$ 液 $500 \mathrm{cc}$ の静注を賞用している. しか しこれらは理論的にはよいが，実際的ではない。すなお らブドウ糖は最も使用される薬郕であるが, 必ずしもこ れのみで全治は期待し得られず，今な拈先の応用の方法 について検討が加えられているものと見てよい. 因及に 余らの 1 治験例を紹介して見たい.すなわち第11表に示 した如く, 本例は消化型の典型的なるのと思われ, 血糖 は $35 \mathrm{mg} / \mathrm{dl}$ 抢よび尿のケトン量は $300 \mathrm{mg} / \mathrm{dl}$ V達して いた。よって $40 \%$ ブドウ糖を 1 日 1 回 $500 \mathrm{cc}$ 宛 5 日注射 したところ, 注射開始 3 日目から著しく快方に向い, 第 5 日には臨床上治癒と認めたが, 第17日の検査結果的ら

第11表 Ketosis の治療試験(ホル種，守，4才)

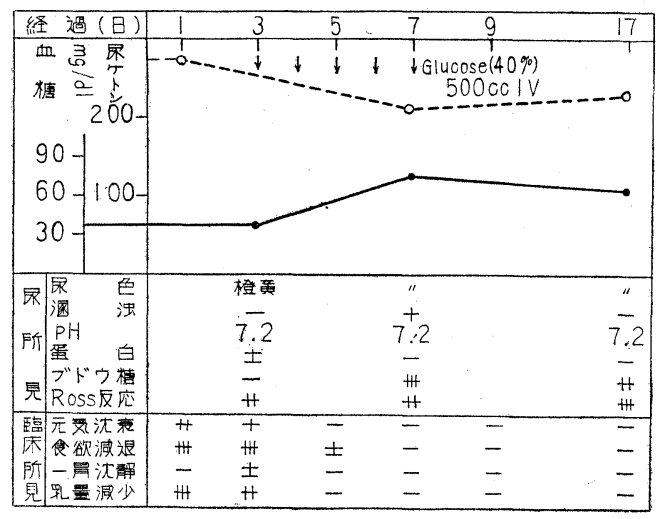

日獣会誌 10 (1957) 
見ると，その間の飼養管理の欠陥の影響のように推察さ れる.

\section{2. グリセリン末よびプロピレーングリコール}

Chamber \& Douel (1925) が脂肪代謝時の組成物質 として Glycerol を取りあげ，これがブドウ楉に変化す ることを犬で認めて以来，ケトーシスに対する治療㓮と して Glycerol の応用研究が試みられた。すなわちグリ セリンははじめ羊を実験動物として，すべて経口的泟与 えられ，これがブドウ糖化変るとし(DURES), 第 1 胃内 に怙ける醱酵機構掞よび吸収などが検討された(GRIFFITHs, Forsyth, Jones). 次いでケトーシスへの応用試験 が行われ(Johsson), 1 日 $500 \mathrm{~g}$ 宛 5 日間経口投与がよい とされたが, 結局 0.5 1.0pint を1日 2 回に分け, 数 日与党ることがよいようである.さらにグリセリンに代 るに Propylene glycol が取り上げられ(Jonnson), グ リセリンよりプロピレーングリコールの方が少量で効果 ありとされ，1日 200 400g を2 回数日 (Johnson) あ るいは $250 \mathrm{~g}$ を1日 2 回 4 日間与えるとよいと報ぜられ た (MAPLESDEn). しかしこれは過量な場合は有害なり との警告が発せられている. 以上の如く,グリセリン拉 よびプロピレーングリコールは最近に特ける治療研究の 対称とされているが，実際には高価なため一般の使用に は適さない。やがて実用化の時代が到来することと思わ れる。

\section{3. その他有機酸塩}

(1) Sodium propionate: 有機酸塩で最も賞用され ているのはプロピオン酸ナトリウムである．これは $\mathrm{Sc}-$ HULTZ (1952) がはじめて桾形成有機酸塩として，1日 $11 b$ 宛 8～10 日連日経口投与し, ケトーシスの治療特よ び予防の目的で用い农のであるが, その結果, 血糖の增 量, ケトン体の減少扮よび乳量の增加をきたし, 臨床症 状子好転している. その後実際に治療的效果が認められ (Fincher, ShaW ら), 用法についても $1 \mathrm{bb} 2 \sim 3 \mathrm{oz}$ の水に溶き，1日2回経口投与すること(MILLS), ある

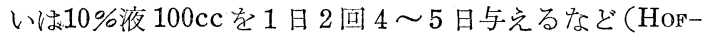
LUND ら）種々な報告が出された.

著者らの研究室に抒いても若干の試験を行い, その成 績はすでに報じたところであるが，ここにその 2 例を紹 介することとする。すなわら第12表は臨床上食㴖と診断 され，また第13表はケトーシスと判定された例である が，ともに Pionateを1日100g宛10日連日投与したも のである. その結棸，ケトン量の滅少，ブドウ糖の增量 をきたすとともに臨床症状は好転して回復した例であ る.すなわちプロピオン酸ナトリウムは, ケトーシスの 久ならず第 1 胃の活動を阻害する如き疾患沁応用しても 好結果をもたらするのの如くである。

(2) Ammonium lactate : 乳酸アンモニウムは $\mathrm{S}_{E-}$

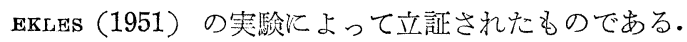

第12表 食滞牛に対万す Pionate の投与試験

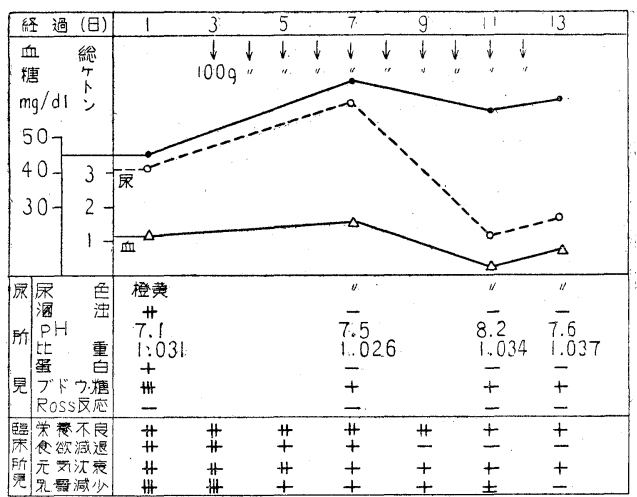

第13表 Ketosis 牛に対する Pionate の投与試騒

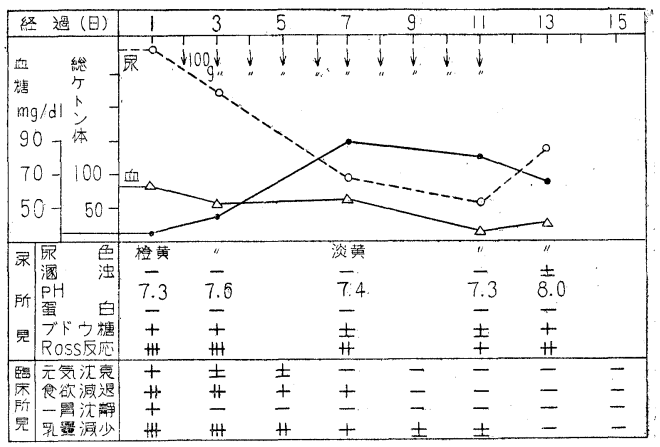

彼は本剤 $120 \mathrm{~g}$ 1 1 int の水汇溶解し，1日1～2 回 宛 5 日連続経口投与したところ, 肝臟化 lactate 学供給 することにより，肝機能を好転して肝のグリコーグンの 含有量も增加したと述べている。しかしながら, 現在の ところ臨床上余り使用されず，むしろプロピオン酸ナト リウムの方が広く応用されている。

(3) Calcium gluconate : グルコン酸カルシウムは $20 \%$ 液が用いられ，1日1回 $250 \mathrm{cc}$ 宛静注し，また同時 に同量を皮下に注射する。この方法を数日反復すること により，とくに神経性のケトーシスに効果ありと(UDALL). 本剤を静注する場合, 早き飞失すると薬剤のコロ イド化をきたし死を招来するため, 緩徐注射すべきで あるといら (GeNGOUX).

(4) Sodium Salicylate (SproulL) 拈よび Sodium ethyl oxalacetate (RoBer ら) が, これらの糖化能 を利用して，極く最近試験的に用いているが，未だ応用 の域に達していない。

\section{4. その他有機物}

(1) Choline chloride: 塩化コリン $5 \%$ 液 5〜10gを 静注する。これは脳下垂体一副腎皮質系学刺激すると思 われるという(TALSMA).

(2) Chloral hydrate: 抱水クロラールは専ら神経 型尓トーシスに用いられたが， $30 \mathrm{~g}$ 宛 1 日 $1 〜 2$ 回カプ 
セルで与えるか，また 1 pint の糖密水あるいは水溶液 として用いている(UDALL). 本剤は血糖值を上萛せしめ るが, 乳熱との合併症ある場合または疲労はなはだしき 患牛には危険である(SAMPSON)。 また本剤 $0.5 \mathrm{oz} を 1$ pint の水汇溶解し， 1 日 2 回宛 $2 \sim 3$ 日投与寸ると効 を奏するが，さらに糖形成物質，ACTH，Hydrocortisone あるいは Cortisone acetate とをそれぞれ併用す ると, 効果はさらに顕著である(KELLY).

\section{5. 無機塩類}

(1) Normal saline solution: 数ガロンの生理食塩 水汇 $0.09 \sim 0.13 \mathrm{~g} の$ apomorphine hydrochloride 加光，これを注射すると，神経型ケトーシスに良效を奏 する(H.AYRS).

(2) Sodium bicarbonate: 重曹 250 500g 学経口 投与するとアシドーシスを消退させるが，これは代謝に はなんら関係ない(UDALE).

(3) Chlorate : 塩素酸塩のうち，2つが用いられて いる.

ずなわち塩素酸カリウム $\left(\mathrm{KClO}_{3}\right)$ を日量 50 ～70g宛 $500 \mathrm{cc}$ の水飞溶解して，3〜5 日経口投与し，また塩素 酸ナトリウム $\left(\mathrm{NaClO}_{3}\right)$ を日量 $60 \sim 80 \mathrm{~g}$ 宛前者と同様 経口的汇与觉るが，とも塩素酸イオンの作用汇よるも のなりと.さら塩化カリウム $(\mathrm{KCl})$ を日量 $40 \mathrm{~g}$ 宛 3

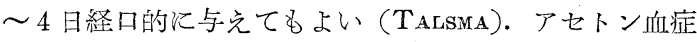
では血中の Kの低下をきたすが，これは副腎皮質の機能 低下によるもので, 治療には $\mathrm{KCl}$ と副腎皮質の抽出物 がよいという(CARLSTROM).な物 ACTH 塩素酸カリ ウムまたナトリウムを $25 \sim 35 \mathrm{~g}$ 宛 1 日 2 回与兄ると, 極めて治療效果があるといわれる(TALSMA).

\section{6. コバルト}

ケトーシスが鈗物質の不足によるものの如しとの考克 から、コバルト療法を行ったものもいる。すなおち硫酸 コバルト $1 / 160$ 液 $2.5 \mathrm{oz}$ を(HENDERSON), また同じく $0.5 \mathrm{oz}$ を，关れぞれ毎日経口投与した（HUNTER ら， SAMPSON）結果, 食欲旺盛となり,ケトーシスの症状は 消退せりといわれる。最近W W HITE は，ブドウ糖を静注 した後, $1 \mathrm{oz}$ の疏酸コバルトを 1 gallon（約 $3.8 \mathrm{~L}$ ) の 水に溶解し， $2 \sim 3 \mathrm{oz}$ 宛毎日経口的に与充たところ， 2 〜24時間から食欲良好となり，しかもコバルトを与克る と $\mathrm{VB}_{12}$ の合成を促進させるようであると称している. しかしながら，コバルト投与により效を奏した地带は， いずれもコバルト久乏地帯の感があり，ケトーシスとの ものとコバルトとは, 代謝面から考兄疑閥視されるとこ ろが多い。

\section{7. ビタミン}

ケトーシスの治療に, VAは效なく(Hayden, ShaW), $\mathrm{VB}_{1}$ は 1 回 $0.5 \mathrm{~g}$ 宛の静注で著效むり (UDALL) といわ 礼る。ささらに $\mathrm{VB}_{12} 1 \mathrm{mg}$ 宛経口投与がよいと（HUNTER
ら）されているが，これは前述のコバルトと関連性を有 している.

\section{8. 蛋白䁲}

ケトーシスが蛋白代謝に大い関係ありとの考克か ら, 本症の治療执よび予防任蛋白質が必要とされてい る.す來わらとくにこれを強調したのはVIGUE (1952) で，彼はカロリ一供給の必要性から蛋白質を取り上げ， これにはアミノ酸就中動物蛋白質を推賞している.そし てケトーシスでは肝障害が多いゆ光，これ亿は高蛋白の ものおよび特殊の lipotropic substance すなわちコり ン, メチオニン, 肝抽出物が好をしく, lipotropic substance を含を栄羕源たる高蛋白飼料を用いた．彼は実 際的にはブドウ糖にアミノ酸を添加している.すなわち カゼインの加水分解により得た溶液 (parenamine) の 15\%液 100cc に，ブドウ糖15\%液 300ccを加克静か清静 注するが，むしろこれは胃腸壁から容易深叹されるか ら経口的汇与学る方がよいと述べている。 SHAW らも VIGUE と同様な見解を持ち，また $10 \%$ の割合で動物蛋 白を与えたところ, 本症の治療および予防に卓効ありと され (CROOPsv), さらに蛋白欠乏と肝障害とは密接な関 係を有し(LILLIE ら)，高蛋白拄取によって該障害肝の 良転を見るため,メチオニンは肝の代謝汇は重要なるの であるという(BUTT \& SNeLL,FAGIN \& $Z_{\mathrm{INN}}$ ). このよ うな点から，メチオニン製剤を併用することも本症の治

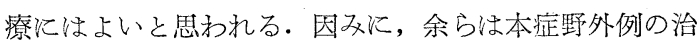
療に,メチオニン剤を試験的併用した。すすおち第14 抢よび第15表に示した如くであるが，さらに追試の要が ある。

第14表 Ketosis の治療試験

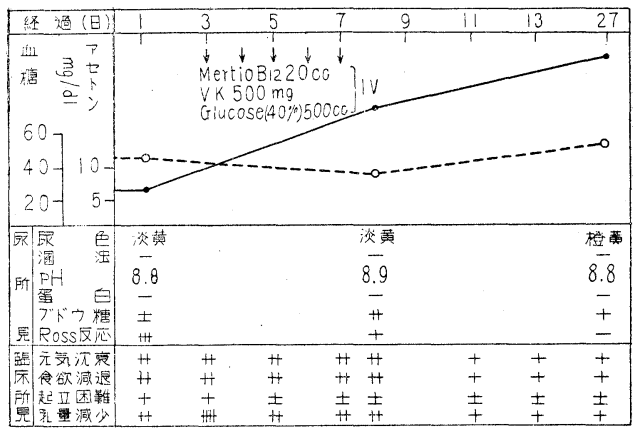

第15表 食欲不振牛の治療

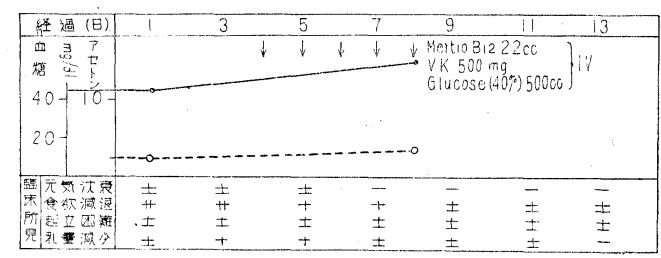

日獣会誌 10 (1957) 


\section{9. ホルモン}

ケトーシスが脳下垂体一副腎皮質系ホルモン の不均衡によるという，いわゆる内分泌学的考 察が行われ，これを基調とする治療法が考究さ れてきた.この中最も代表的なものはCortisone および ACTHで，この両者に関する研究はお びただしい発展を遂げた。しかしてこれらホル モン剤は直接血糖およびケトン体の增減に参与 するものではなく, 糖代謝に関係して間接にケ トーシスを治癒させるものと解されている。

(1) $\mathrm{ACTH}: \mathrm{ACTH}$ (Adrenocorticotropic hormone) は副腎機能を促進させ glucocorticoids の分泌を促すことから, SHAWら(1951) がケトーシスの治療に用いて以来, 多くの研究 者が (Anon, Christian \& Segard, Jordan, Kerr, Larsen, Laeuwarden, McAultff, MCGIRR, SAMPSON) これを認め, その使用法 についても種々検討されている. 注射方法も研 究者により異なり，1.0g 1 回 (ANON, ShAW ら), $50 \mathrm{mg}$ 宛12時間毎(LAEUWARDEN), 200mg(JORDAN) など様々で あるが, 病勢により異なるようであり,治癒率も最近では 90\%代となっている。とくに興味を引くのは C五ISTIAN \& $\mathrm{S}_{\mathrm{EGARD}}(1953)$ の方法である.彼らによると, Aspirin 投与によって肝のグリコーゲン量を低下させ(RATE), ま たサルチル酸は肝の炭水化物の代謝機能を変化させるも のなることからSEGARDはACTH がアスピリン併用によ り節約できるとした.すなわちACTH 20 単位を筋注し, 同時に 1 日 3 回 3 日間, 400 単位の VC および $4 \mathrm{mg}$ の $\mathrm{VK}$ を含有するアスピリン $4 \mathrm{~g}$ を与えた。 その後 $\mathrm{ACTH}$ $50 \mathrm{mg}$ を皮下注また筋注し，同時にアスピリン $4 \mathrm{~g}+\mathrm{VK}$ $4 \mathrm{mg}$ を1 日 4 回投与することを推賞している。 また $\mathrm{ACTH} 200 \mathrm{mg}$ とブドウ糖, および $\mathrm{VB}_{12} 200 \mathrm{mg}$ の併 用によって $90 \%$ の治癒率を見(JORDAN), さらに極く最近 ROSENBERGER は ACTH 100 単位を $1 \sim 2$ 回筋注し, 同時にプロピオン酸ナトリウムを 1 日 $50 \mathrm{~g}$ 宛数日経口 投与して好成績を挙げている。

(2) Cortisone：これは glucocorticoids を含む副腎 皮質ホルモンで, $\operatorname{SHAw}(1947)$ によって副腎皮質抽出物 がケトーシスに效果めりとされたことにはじまるようで ある. 彼は Cortisone 0.9〜1.5g を筋注し，さらに 24 〜72時間後に $1 \mathrm{~g}$ を注射した結果, 血糖量の増加掠よび ケトン量の減少を見, 嵒床症状も快方に向うことを確認 せる後, さらに彼は cortisone acetate より hydrocortisone の方が有效なることを報じた. 爾来多くの研 究者によってその效果が立証されると同時に，本郕の改

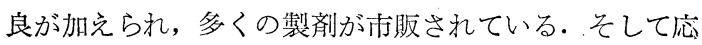

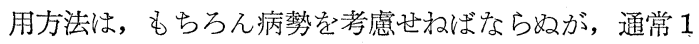
回 $500 \mathrm{mg}$ を注射するのがよいと思われ，また一般に
第16表

第17表

$\operatorname{Ketosis}($ 古, 7 才, 分婏後 5 日)

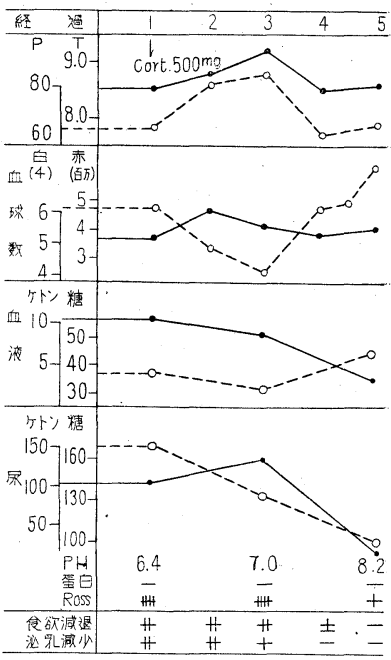

hydrocortisone がよいとされている. 一方 Cortisone を与えると，蛋白からブドウ糖形成を促すため治療に用 いられるが，ブドウ糖形成のため蛋白を用いるのは，牛 にとって浪費的の過程であり，よって揮発性脂肪酸の生 産割合を統制できる如く，第 1 胃内の醱酵につき十分 なる検討を加えることが必要なりと称するものもいる (Johnson). 因みに, Cortisone $500 \mathrm{mg}$ 注射による治験 2 例を，第16执よび第17表に紹介して見たい。

(3) APL：脳下垂体前葉ホルモンは過去に掠いて用

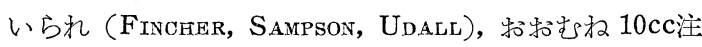
射しているが，これは肝のグリコーゲンや蛋白質から， ブドウ糖の産生を促し，血糖を上䒜せしめるとのことで ある.しかし, 現在, ケトーシス治療の目的では余り用 いられない。

(4) Insuline : オランダでは 100〜150 単位のインシ ニリンにブドウ糖 $200 \mathrm{mg}$ を $1 \mathrm{~L}$ の水にとき, 消毒冷却し て $3 \sim 4$ 力所に分割皮下注し (SJOLLEMA), また200〜400 単位を与えるとする者もいるが (DIERNHOFER)，ともに 血糖上昇に效素奏するものとされている.

(5) Dihydrotachysterol：これはインシュリンとは 異るが，その薬理作用が副甲状腺の抽出物に類似したも ので，英国ではじめて報告されたものである(LEWIs). すなわちVDの製造過程中に得られた油溶成分で，この 製刘である“A.T.-10”（BAYER）を筋注(5cc)また経口 的 $(10 \mathrm{cc})$ に与学ている. 本剤でははじめ $\mathrm{P}$ の低下を見 るが，後に注射前の值に上昇し，また Ca 抢よび血糖の 上昇をきたす。よって分婏後乳牛に与えるとケトーシス を予防すると同時に，治療には Ca を併用するとよいと いらことである.

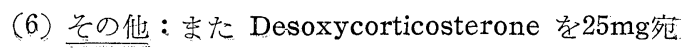


1 日 2 回, 4 回注射し, 同時にブドウ糖 $4 \mathrm{lb}$ を経口投 与した結果，4〜 5 日後に 49 例中約 $80 \%$ 回復したが， その後直ちに高度の飼養を行ったため, 再発したという 報告(VANDEPLASCHE) もある. しかしこの Desoxycorticosterone は性格上, 果して治療刘として適するや否 や疑問とするところである.さらに 11-Ketogesterone 1〜 5g を与えると, Cortisone acetate に比べ血糖の增 量をきたすことから(GIBBONS, SPEICRER)，本剤の有効 なることが認められたが，実際の応用にまでいたってい ない.

以上述べた如く, ケトーシスの治療には, 栄養学的お よび内分泌学的の両面から，それぞれ治療法が考究され ているが, 現在最も通常使用されつつあるのは, ブドウ 糖, プロピオン酸ナトリウム並びにコーチゾンおよび $\mathrm{ACTH}$ である.しかして治療に当っては, まずその病 性を原因学的汁握し, 飼養管理の改善を第一義に, 薬 剤の応用は第二義的のものと考㝋るべきである.

$$
\text { 予防。 }
$$

1. 飼養 鉣物質, 蛋白質, 炭水化物およびビタミン 類を適切に与える如くし，十分なるカロリー打よびェネ ルギーを供給する如く努める．栄養ある飼料を与兄，か つ食欲を旺盛こすることが必要であり(S.AMPSON), ケト ーシスでは肝障害を若起することが多い故, 蛋白の多い もの括よび lipotropic substance すなわちコリン,メ チオニン，肝抽出物などはよい。しかして予防にはこれ らを含有する栄養源たる蛋白飼料が適し，それにはアミ ノ酸が推賞され，実際的には動物蛋白を与えると予防に も治療にも効果がある(VIGUE, S S F.AW). 10\%の割合で動 物蛋白を与光たところ, 本症の予防扣よび治療に效を奏 し，アミ>酸含有のものが最も適しているようである (CROOPsY). また一般には炭水化物給源として, 糖密利 よび砂糖などを混食させているが，この方法もよいし かして underfeeding (CARLSTROM, KelLY) でも, ま た overfeeding でも (Hoflund, LesBodgries ら) ケ トーシスを起すが，後者は高能率牛に不適当な飼料を給 する場合化発するもので，要するにエネルギーの低下を きたしているものであるといわれる。

2. 管理 妊娠の初期および後期, 並びに分婏後の管 理には細心の注意を払い, 適切な飼料の給与と相俟っ て, 牛体の手入执よび運動を行うことが必要である. 運 動は極めて大切で, 運動によりケトン量の減少 $(28.7 \rightarrow$ $22.4 \mathrm{mg} / \mathrm{dl})$ および血糖量の増加（30 $\rightarrow 50 \mathrm{mg} / \mathrm{dl})$ を見 るが，これは運動中副腎皮質から分泌されるアドレナリ ンにより，肝のグリコーゲンの分解が促進されるという (LAEUWARDEN). よって毎日少なくも30分の運動が必要 とされ, かつ同時に塩素酸塩25～35g を500 cc の水に溶 解し，1日，2回宛 3 日投与すると，完全に本症の発生を
予防し得るということである(LAEUWARDEN). 本症が泌 乳過度のものに多いことから, 過重の搾乳をさけ, かつ 酷暑执よび寒冷に対する防除も必要である.

3. 各種疾病, 就中前胃疾患では, ケトーシスを随伴 し易いから、これが原病の治療に万全を期すべきである.

4. その他 プロピオン酸ナトリウムを予防的に(SoHULTZ), また ACTH を分婏前後各 2 週間, 1 週間々隔 で注射する（ROGERS）ことを推賞した報告もある.

以上要するに, 本症の発生機構から考完, 牛個体にも よるが，ストレスを加えざる適切な飼養管理を行うこと が，本症予防の第一義となろ 5 .

文献省略

\section{〔蛋白質抒よびアミノ酸と栄養について(279頁より)] 文献}

1) McCOLLUM : Newer knowledge of Nutrition (1939). 2) I. G. MACY, et al: J. Biol. Chem., 86, 17 (1930). 3) C.K. SHUKERS, et al: J.Nutrition, 4, 399 (1931). 4) W.C. ROSE: Science, 86, 298 (1937). 5) - : Physiol. Revs., 18,109 (1938). 6) —, et al.: Science, 90, 186 (1939). 7) - : Federation Proc. 8, $546(1949)$. 8) - et al.:J. Biol. Chem., 182, 541 (1950). 9) —: Ibid., 193, 605 (1952). 10) —: Ibid., 193, 613 (1952).

11) A.A. ALBANESE : Protein and $d^{3}$ Amino Acid Requirements of Mammals (1950). 12) C.D. BAUER, et al: $J$. Nutrition, 26, 51 (1943). 13) J.R. TOTTER, et al: $J$. Biol. Chem., 127, 375 (1939). 14) H.J. ALMQUIST, et a1 J. Nutrition, 28, 325 (1944). 15) -: Ibid, 34, 543 (1947). 16) L.E. HOLT, et. a1., Federation Proc., 1, 116 (1942). 17) W.C. ROSE, et al.: J. Biol. Chem., 188, 49 (1951). 18) E. T. MERTZ, et a1.: Arch. Biochem., 38, 121 (1952). 19) C. W. DUNCAN, et a1.: J. Nutrition, 49, 41 (1953). 20) A. MEISTER, et a1.: J. Biol. Chem., 191, 211 (1951).

21) H.L. WILliAMS, et al: Science, 103, 654 (1946). 22) W.C. RoSE, et al: J. Biol. Chem., 187, 687 (1950). 23) 一, et al : Ibid, 148, 457 (1948). 24) J.M. ORTEN, et al: Ibid.，160，435 (1945)．25） 览玉：日本医事新報，1229，3 (1947). 26) C. D. BAUER, et al: J. Nutrition, 26, 51 (1943). 27) J.N. WilliaM, et al: J. Biot. Chem, 183, 539 (1950). 28) -, et a1: Ibid., 187, $597(1950) .29) \quad$-, et al: Ibid., 189, 659 (1951). 30) D.B. SPRINSON, et al: Ibid, 180, 707, 715 (1949).

31) R. L.M. SYNGE, et al: J. Agri. Sci., 44, 254 (1954). 32) 一, et al, : Ybid., 44, 263 (1954). 33) —, et al, : Ibid., 44, 270 (1954). 34) B.F. STEELE, et a1: J. Nutrition., 40, $145(1950)$. 35) J.B. KIRSNER, et al : J. Clin. Invest., 28, 716 (1949). 36) SAMPSON : Biochem. J., 26, 1315 (1932). 37) GAL. : Biochem. Zs., 225, 286 (1930). 38) STUMPF: GREEN.: J.Biol. Chem., 153, 387 (1944).

乳中の $\mathbf{C a} \subset \mathbf{P}$ 泌乳能力の高い乳牛は 1 日に $\mathrm{Ca}$ 43g, P 37g を乳中に分泌する.

$\mathrm{P}^{32}$ をトレーサーとして用いた実験の結果, 乳中の $\mathrm{P}$

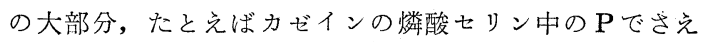
も血獎中の酸溶性 $\mathrm{P}$ からきものであることが分った。

また $\mathrm{P}^{32}$ を乳房中に注入する実験によって, 乳房中

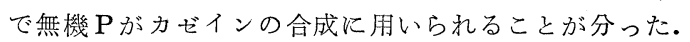

$\mathrm{Ca}^{45}$ 和よび $\mathrm{P}^{32}$ を 1 週間に 53〜 66kg の乳を泌乳する 乳牛に静注したところ， $\mathrm{Ca}^{45}$ の $35 \%$ と $\mathrm{P}$ の $22 \%$ が乳 中に分泌された. (KLeIber, M. et al. : Ann. N.Y. Acad. Sci. 64, 299, 1956.-Vet. Bull. 27, 135,1957)

日獣会誌 10 (1957) 